\title{
Interleukin-5 Receptor Subunit Alpha
}

National Cancer Institute

\section{Source}

National Cancer Institute. Interleukin-5 Receptor Subunit Alpha. NCI Thesaurus. Code C26269.

Interleukin-5 receptor subunit alpha (420 aa, $48 \mathrm{kDa}$ ) is encoded by the human IL5RA gene. This protein is involved in the modulation of interleukin- 5 signaling. 